\title{
DECISION-MAKING MODEL SUPPORTING THE PROCESS OF PLANNING EXPENDITURES FOR RESIDENTIAL BUILDING RENOVATION
}

\author{
Robert BUCONं*, Michał TOMCZAK \\ Department of Construction Project Engineering, Faculty of Civil Engineering and Architecture, \\ Lublin University of Technology, Nadbystrzycka 38 D, 20-618 Lublin, Poland \\ Received 08 January 2016; accepted 05 July 2016
}

\begin{abstract}
The problem of multi-family building maintenance is complex and comprises numerous issues, one of which is the process of planning expenditures for residential building renovation. This task is important from the manager's point of view as their responsibility is to maintain a building in a non-deteriorated condition. To fulfil this task, the authors of this paper suggest utilising a decisionmaking model aimed at defining renovation activities making it possible to retain the maintenance standard (as regards newly commissioned residential buildings) or improve it (as regards existing buildings). The suggested model is based on a multi-criteria building assessment including seven requirements. The calculations conducted using the suggested model enable us to define the costs and scope of renovation taken to ensure the assumed building condition or, by assuming various rates paid to the renovation reserve, to define the period in which the above-mentioned goals may be achieved.
\end{abstract}

Keywords: renovation planning, building maintenance, decision-making model, building condition assessment, building condition criteria, selection of renovation.

JEL Classification: C61, L74, R31.

\section{Introduction}

Residential building management in Poland requires that buildings should be maintained in a non-deteriorated condition and obliges managers to legitimately invest financial means earmarked for renovation, i.e. (Journal of Laws - The Real estate management 1997). The task of maintaining residential buildings faces two basic problems which result from two unregulated and mutually influencing issues. The first issue refers to the Construction Law regulations that oblige a manager to maintain a building in a non-deteriorated condition,

${ }^{\star}$ Corresponding author. E-mail: r.bucon@pollub.pl 
however, they do not define the standard of its maintenance. The other issue is the problem of financing the building maintenance expenditures resulting from the lack of sufficient funds for this purpose in planned renovation budgets.

In Poland, as well as many other countries, the assessment scope of multi-family residential buildings includes almost exclusively technical condition and excludes other criteria of building condition or their residents' needs and expectations (Bucoń, Sobotka 2015). The limited scope of building assessments fails to provide information necessary to define expenditures necessary to ensure a correct level of building maintenance (Bahr, Lennerts 2010). Lack of information for determining the amount of contributions to the renovation fund is the cause of not ensuring sufficient financial means to meet all renovation needs in the building. That's why, the execution of the building renovation is limited only to repairs resulting from a restrictive assessment of the building condition. Negligence in the buildings' maintenance as a consequence of such approach will adversely affect the utility and market value of buildings (Bucoń, Sobotka 2015).

In the first part of the article the authors analyzed current studies on the issue of the assessment of the building state and the support of decision-making process of residential buildings. Recognition and analysis of methods and models presented in the literature formed the authors' study basis to develop an innovative method supporting the administrator in the process of budgeting for the maintenance of residential buildings. The stages of the proposed model and its exemplary use are shown in the second and third part of the article. In the summary the advantages and disadvantages of the proposed decision-making model are indicated and the area if its application is identified.

\section{Methods and models for building maintenance}

In order to provide an adequate level of building maintenance, a comprehensive assessment of a building condition is required (Straub 2009; Christen et al. 2014). This assessment, expressed with numerous indicators (building condition, use value), is done by the use of multiple-criteria methods defined in the literature as MCDM (Multiple Criteria Decision Making). Studies carried out on their application resulted in many suggestions of assessment models, which differ in terms of method and scope of assessment as well as computational techniques used (Medineckiene et al. 2015; Kaklauskas et al. 2005). Researchers point to the need for broader assessment of a building condition than it is currently present. They also emphasize the importance of assessment taking into account a number of requirements, to which a residential building should correspond. These requirements can be devided into those arising from the law (Kasprowicz 2005), as well as those resulting from economic, ecological, social, cultural, architectural and technical reasons. Examples of multi-criteria methods to assess a building condition can be found in the works (Bucoń, Tomczak 2016; Medineckiene et al. 2015; Mickaityte et al. 2008; Kaklauskas et al. 2005). A wider range of building assessment including, among others, environmental reasons is present in the methods of LEED, BREEAM, DGNB, EU GreenBuilding, Green Star, CASBEE, BEPAC and others (Medineckiene et al. 2015; Reed et al. 2011; Alchimoviene, Raslanas 2011). Some building assessment models, e.g., used to select a maintenance strategy also take into account other 
criteria concerning indirectly to its maintenance, i.e., the rights and responsibilities of administrator, record keeping, planning current activities (e.g. cleaning), emergency preparedness, financial plans (planned and unplanned expenditures) (Chua et al. 2015; Ho et al. 2012; Ho et al. 2008; Yau et al. 2008).

Comprehensive assessment of a building allows to determine renovation needs. However, a key objective of a maintenance process of residential buildings remains planning renovations and providing funds for their implementation. Examples of methods for budgeting are presented in the works of Christen et al. (2014) and Mohd-Noor et al. (2011). An innovative solution based on numerous statistical analyses covering empirical maintenance costs is socalled PABI Budgeting Tool (Practical, Adaptive Budgeting of Maintenance Measures) presented in the work (Bahr, Lennerts 2010). Another issue related to the building maintenance is the problem of building maintenance cost optimization. The aim of the research is to develop methods for selection the most favourable renovation variants within given funds (Bucoń, Tomczak 2016; Zavadskas et al. 2008; Yin et al. 2011). In the literature the method for supporting a decision-making process, in which the proposed solutions used for the optimal allocation of renovation funds are called DSS (Decision Support System). They are based on expert systems (Borissova, Mustakerov 2012) and AI (Artificial Intelligence) methods utilising fuzzy sets (Bucoń, Sobotka 2015), neural networks, evolutionary algorithms, etc. (Juan et al. 2009; Perng et al. 2007). The examples of other DSS systems based on the stochastic approach include: BMDSS (Building Maintenance Decision Support System) developed by Langevine et al. (2006) and BELCAM (Building Envelope Life Cycle Asset Management) developed by Lounis and Vanier (2000). In the literature other methods based on multi-criteria methods such as AHP, ELECTRA, TOPSIS, SAW, COPRAS can be found. These methods are used for evaluating and selecting renovation and modernization scenarios (variants) of buildings in order to improve buildings' condition and carry out technical and economic comparisons of the proposed repair variants (Rasiulis et al. 2016; Raslanas et al. 2011; Zavadskas et al. 2008; Kaklauskas et al. 2008). The computer examples of integrated systems to diagnose a building condition and make decisions about the way and scope of renovation works with particular emphasis on thermo-modernization works are: TOBUS system (European diagnostics and decision-making Tool for Office Building Upgrading Solutions) developed for office buildings (Caccavelli, Gugerli 2002), EPIQR (Energy Performance and Indoor Quality Retrofit) for residential buildings (Kolokotsa et al. 2009) and XENIOS system to assess hotel facilities (Dascalaki, Balaras 2004). Another example of a more comprehensive computer system to improve the maintenance quality and reduce the maintenance costs is BASE-FM system (Dukić et al. 2013). New solutions for buildings' maintenance are also provided by modern technologies based on computer networks (Ko 2009).

\section{Description of the suggested model}

The suggested decision-making model constitutes a complex calculation problem comprising three main stages presented in Figure 1. Solving these problems requires using appropriate methods discussed hereunder. Implementation of the model makes it possible to fulfil two main tasks. The first task consists in determining, for the assumed maintenance period, the 


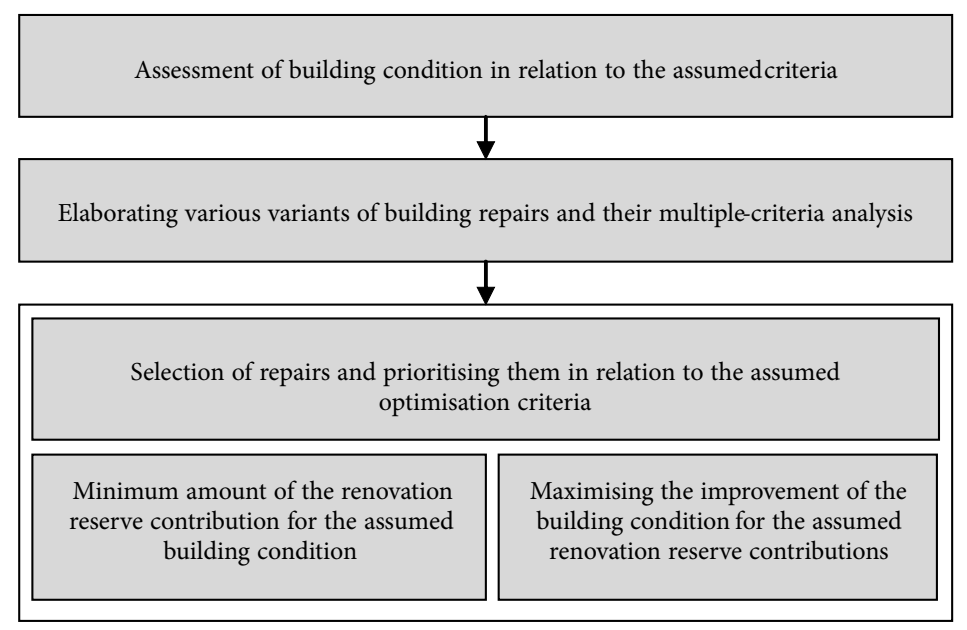

Fig. 1. Stages of the suggested model

most advantageous scope of renovation works, assuming the minimum cost of achieving the assumed improvement of the building condition as the optimisation criterion. The second task consists in determining, for the assumed maintenance period, the scope of renovation most advantageous for the renovation budget obtained from monthly contributions to the renovation reserve assuming the maximum improvement of the building condition as the optimisation criterion.

See Sections 1.1-1.3 for a detailed description of individual stages of the elaborated model including the description of calculation methods used.

\subsection{Assessment of building condition criteria}

In order to assess a building for the assumed building condition criteria $o_{i k l}$, the "weighted average" principle (1) was used where individual $a$-th elements of an $l$-th building influencing a $k$-th criterion are assessed using a 5-degree linguistic assessment scale, i.e. very good (VG - 10 pts), good (G - 7 pts), medium (M - 5 pts), bad (B - 3 pts), very bad (VB 1 pt) and $\mathrm{N}$ - not assessed. Intermediate scores may also be used, i.e.: VG/G (9), G/VG (8), G/M (6), M/B (4), B/VB (2). The scope of particular building condition criteria may include specific number of building elements. The influence assessment of $a$ elements on $k$-th criterion can be defined with the use of many methods, e.g. pseudo-fuzzy scaling method (Bucoń, Sobotka 2015).

$$
o_{i k l}=\sum_{a=1}^{A} w_{k a l} \cdot O_{k a l}, \quad i=0, \forall k=1,2, \ldots, m, \quad \forall l=1, \ldots, L,
$$

where: $w_{k a l}, O_{k a l}$ - respectively weight and assessment of $a$-th element in an $l$-th building for $k$-th building condition criterion; $m$ - number of assumed criteria; $A$ - number of assessed elements for each building condition criterion; $L$ - number of buildings. 


\subsection{Multiple-criteria assessment of suggested repairs}

The assessment of aelements of a building using the linguistic terms constitutes the basis for determining necessary renovation activities in a building. The suggested building repairs may exert various impacts on improving the assumed $k$-th building condition criteria. They may be conducted in various ways, i.e. variants $(r=1, \ldots, q)$, each of which presents a different solution as regards the materials and technologies used as well as the costs incurred.

The $P_{k a r l}$ assessment is conducted by means of the following linguistic terms, i.e. very large (VL), large (L), medium (M), small (S), very small (VS). Each term has an applicable value, i.e.: 10, 7, 5, 3 and 1 pt. Intermediate scores may also be used, i.e.: VL/L (9), L/VL (8), L/M (6), M/S (4) and S/VS (2). When a repair contributes to improving building condition criteria assessment, the values are positive. Otherwise, they are negative. Estimation of $k$-th building condition criterion improvement value resulting from the $r$-th repair variant in an $l$-th building results from the following Eq. (2):

$$
p_{k r l}=\sum_{a=1}^{A}\left(Q_{k a l}-O_{k a l}\right) \frac{P_{k a r l}}{q_{k a r l}} w_{k a l}, \quad \forall k=1, \ldots, m, \quad \forall r=1, \ldots, q \quad \forall l=1, \ldots, L,
$$

where: $Q_{k a l}$ - maximum value of the assessment of an $a$-th element condition in relation to a $k$-th criterion in an $l$-th building; $q_{k a r l}, P_{k a r l}$ - respectively: maximum possible score and assessment of the influence of an $r$-th repair on improvement of the condition of an $a$-th element assumed to assess a $k$-th criterion in an $l$-th building; $w_{k a l}$ - weight of an $a$-th element of an $l$-th building in relation to a $k$-th criterion (when $\sum_{a=1}^{A} w_{k a l}=1, \quad \forall k=1, \ldots, m, \quad \forall l=1, \ldots, L$ ).

The condition assessment of buildings $S_{i}$ for an $i$-th maintenance period is a weighted average of scores from $k$-th building condition criteria where the weight is the $P_{l}$ usable area of each $l$ building and the $v_{k}$ criteria weight vector. It is calculated by means of the following formula (3):

$$
S_{i}=\sum_{k=1}^{m} \sum_{l=1}^{L} o_{i k l} \frac{P_{l}}{P} v_{k}, \quad \forall i=1, \ldots, n,
$$

where: $v_{k}$ - weight of a $k$-th criterion (when $\sum_{k=1}^{m} v_{k}=1$ ); $P$ - usable area of all $P=\sum_{l=1}^{L} P_{l}$ buildings; $n$ - last analysed maintenance (accounting) period during which buildings are assesses, expressed in years.

\subsection{Selecting and prioritising building repairs}

It is usually impossible to include all suggested repairs in a renovation plan as their total cost exceeds the funds (from the renovation reserve contributions) available to the building manager. In such cases, the most advantageous scope of renovation is determined from the suggested repair variants. Two optimisation model concepts have been developed to solve the above-mentioned problem.

The first model variant is focused on a solution ensuring the highest improvement of the building condition at a given amount of the annual budget $c$. The goal function Eq. (4) 
maximises the assessment of the $S_{i}$ condition for the assumed $L$ buildings. The limit (5) states that the building condition assessment in an $i$ period is the sum of the building condition improvement value resulting from the renovations conducted in an $i$ period and the condition assessment from the previous year. It is assumed that renovation is performed only from own funds, i.e. included in the budget, thus the Eq. (6) states that the $K_{r l}$ renovation costs must not exceed the amounts of budgets for the particular years of the maintenance period. The possible order and dates of repairs depend on the funds in the budget. The Eq. (8) also includes obtaining the assumed threshold value for the building condition assessment defined as $g_{k}$, during a given $i$-th maintenance (accounting) period. The Eq. (9) shows limiting of the choice to one repair among the suggested variants. The Eq. (10) ensures the binary character of the $x_{i r l}$ variable. The mathematical model of the described approach is as follows:

$$
\begin{gathered}
z_{1}: \max z_{1}=\sum_{i=1}^{n} S_{i} ; \\
o_{i, k, l} \geq o_{i-1, k, l}+\sum_{r=1}^{q} p_{k r l} \cdot x_{i r l}, \quad \forall i=1, \ldots ., n, \quad k=1, \ldots, m, \quad \forall l=1, \ldots, L ; \\
(i-1) \cdot c+C \geq \sum_{i=1}^{n} \sum_{r=1}^{q} x_{i r l} \cdot K_{r l}, \quad \forall i=1, \ldots, n, \quad \forall l=1, \ldots, L ; \\
c=P \cdot s \cdot 12 ; \\
\sum_{r \in S_{a l}} \sum_{i=1}^{n} x_{i=1}^{L} o_{i k l} \geq g_{k}, \quad \forall k=1, \ldots, m ; \\
x_{i r l}=\left\{\begin{array}{l}
1, \text { when renovation variant } r \text { is performed in an } i \text { year for an } l \text { building } \\
0, \text { otherwise, }
\end{array}\right.
\end{gathered}
$$

where: $S_{a l}$ - a set of mutually exclusive repair variants in relation to one element; $K_{r l}$ - cost of an $r$-th variant of repairing an element of an $l$-th building; $c$ - annual amount of the building budget; $C$ - starting capital; $s$ - renovation reserve contribution.

The second model variant assumes that the lowest cost of renovation aimed at the intended improvement of building condition $h$ must be determined. To achieve it, the previous goal function Eq. (4) was replaced with the Eq. (11). Obtaining the assumed $h$ value of the condition of all $l$ buildings for an $n$-th maintenance period is shown in the Eq. (12):

$$
\begin{gathered}
z_{2}: \min z_{2}=c, \\
\sum_{k=1}^{m} \sum_{l=1}^{L} o_{i k l} \cdot v_{k} \geq h, \quad i=n .
\end{gathered}
$$

\section{Example of application}

The analysis includes three multi-family residential buildings constructed in OWT 67 prefabricated technology of various usable areas, i.e.: $P_{1}=3200 \mathrm{~m}^{2}, P_{2}=2500 \mathrm{~m}^{2}$ and $P_{3}=3500 \mathrm{~m}^{2}$. They were completed in the 1970's and as archival records state there was no major renovation made. The range of building maintenance was restricted to current maintenance and 
minor repairs. Their assessment takes into account seven building condition criteria, i.e.: $k_{1}-$ structure safety; $k_{2}$ - energy savings; $k_{3}$ - noise protection; $k_{4}$ - hygienic conditions; $k_{5}$ - fire safety; $k_{6}$ - functional safety; $k_{7}$ - building aesthetic appearance. Building condition criteria described refer to significant aspects, from the administrator's point of view, who cares about obeying the law (technical and utility criteria) and the habitant paying attention to utility and economical advantages (thermal, acoustic and aesthetic criteria). Each requirement was connected with a given set of features, i.e. elements assessed using linguistic terms - see 2.1. Description of accepted building condition criteria can be found in such studies as Ho et al. (2012); Juan et al. (2009); Yau (2008); Kaklauskas et al. (2005). Estimation of the weighted average score for each requirement in line with the Eq. (1) preceded by calculating the $w_{k a l}$ element weight values by means of the pseudo-fuzzy scaling (Bucoń, Sobotka 2015). See Table 1 for the results of assessments and calculations for one building.

On the basis of the performed assessment of $k$-th building condition criteria $o_{i k l}$ when $i=$ 0 (initial assessment), for each building, a set of repairs $F=\left(f_{11}, f_{12}, \ldots f_{A q}\right)$ was suggested. These repairs may be performed according to one of the $r$-th variants. The number of repairs/ variants for each building is respectively: $B_{1}(11 / 27), B_{2}(11 / 27)$ and $B_{3}(12 / 29)$. Repairs are suggested for $O_{k a l}$ elements whose assessment result for at least two criteria is bad (B) or very bad (VB). See Table 2 for the assessments of the influence of three repair variants on improving the criteria values (on the basis of Section 2.2) for one element (external walls) of the first building.

Table 1. Assessment of elements $O_{k a l}$ of building condition criteria $o_{i k l}$ for the first building $(l=1, i=0)$

\begin{tabular}{|c|c|c|c|c|c|c|c|c|c|c|c|c|c|c|c|}
\hline \multirow{3}{*}{$a$} & \multirow{3}{*}{ Element } & \multicolumn{14}{|c|}{$O_{k a l} / w_{k a l}$} \\
\hline & & \multicolumn{14}{|c|}{$k$ building condition criterion number } \\
\hline & & \multicolumn{2}{|c|}{1} & \multicolumn{2}{|c|}{2} & \multicolumn{2}{|c|}{3} & \multicolumn{2}{|c|}{4} & \multicolumn{2}{|c|}{5} & \multicolumn{2}{|r|}{6} & \multicolumn{2}{|c|}{7} \\
\hline 1 & Walls & B & 0.27 & VB & 0.34 & $\mathrm{M} / \mathrm{B}$ & 0.41 & VB & 0.17 & $\mathrm{G} / \mathrm{M}$ & 0.21 & & $\mathrm{~N}$ & VB & 0.19 \\
\hline 2 & Roof & $\mathrm{M} / \mathrm{B}$ & 0.17 & $\mathrm{~B}$ & 0.16 & $\mathrm{M}$ & 0.23 & VB & 0.15 & $\mathrm{M}$ & 0.18 & B & 0.10 & $\mathrm{VB} / \mathrm{B}$ & 0.07 \\
\hline 3 & Vestibule & $\mathrm{M} / \mathrm{B}$ & 0.04 & \multicolumn{2}{|c|}{$\mathrm{N}$} & \multicolumn{2}{|c|}{$\mathrm{N}$} & $\mathrm{B}$ & 0.06 & $\mathrm{M}$ & 0.06 & B & 0.18 & $\mathrm{~B}$ & 0.10 \\
\hline 4 & Balconies & $\mathrm{VB}$ & 0.20 & VB & 0.07 & \multicolumn{2}{|c|}{$\mathrm{N}$} & VB & 0.08 & \multicolumn{2}{|c|}{$\mathrm{N}$} & B & 0.14 & B & 0.11 \\
\hline 5 & $\begin{array}{l}\text { External } \\
\text { joinery }\end{array}$ & \multicolumn{2}{|c|}{$\mathrm{N}$} & VB & 0.19 & B & 0.27 & VB & 0.13 & $\mathrm{M} / \mathrm{B}$ & 0.16 & B & 0.08 & B & 0.13 \\
\hline 6 & Partition walls & \multicolumn{2}{|c|}{$\mathrm{N}$} & \multicolumn{2}{|c|}{$\mathrm{N}$} & $\mathrm{M} / \mathrm{B}$ & 0.09 & $\mathrm{M}$ & 0.04 & M & 0.05 & $\mathrm{~B}$ & 0.04 & $\mathrm{M} / \mathrm{B}$ & 0.04 \\
\hline 7 & $\begin{array}{l}\text { Water-sewage } \\
\text { system }\end{array}$ & \multicolumn{2}{|c|}{$\mathrm{N}$} & \multicolumn{2}{|c|}{$\mathrm{N}$} & \multicolumn{2}{|c|}{$\mathrm{N}$} & M & 0.07 & \multicolumn{2}{|c|}{$\mathrm{N}$} & B & 0.06 & M & 0.02 \\
\hline 8 & $\begin{array}{l}\text { Electrical } \\
\text { system }\end{array}$ & \multicolumn{2}{|c|}{$\mathrm{N}$} & $\mathrm{B} / \mathrm{VB}$ & 0.04 & & $\mathrm{~N}$ & \multicolumn{2}{|c|}{$\mathrm{N}$} & $\mathrm{B} / \mathrm{VB}$ & 0.08 & B & 0,09 & B & 0.03 \\
\hline 9 & $\begin{array}{l}\text { Central heating } \\
\text { installation }\end{array}$ & \multicolumn{2}{|c|}{$\mathrm{N}$} & VB & 0.09 & & N & VB & 0.07 & \multicolumn{2}{|c|}{$\mathrm{N}$} & B & 0.07 & B & 0.03 \\
\hline 10 & $\begin{array}{l}\text { Basement } \\
\text { floors }\end{array}$ & M & 0.11 & VB & 0.09 & & B & $\mathrm{M} / \mathrm{B}$ & 0,04 & M & 0.11 & G & 0.04 & $\mathrm{M} / \mathrm{B}$ & 0,06 \\
\hline 11 & $\begin{array}{l}\text { Stairs in } \\
\text { staircases }\end{array}$ & M & 0.08 & \multicolumn{2}{|c|}{$\mathrm{N}$} & & $\mathrm{N}$ & M & 0.05 & M & 0.09 & $\mathrm{VB}$ & 0.20 & B & 0.16 \\
\hline 12 & Basement walls & $\mathrm{M} / \mathrm{B}$ & 0.13 & $\mathrm{M} / \mathrm{B}$ & 0.06 & & $\mathrm{~N}$ & VB & 0.14 & $\mathrm{M}$ & 0.06 & & $\mathrm{~N}$ & B & 0.06 \\
\hline \multicolumn{2}{|c|}{$\begin{array}{l}\text { Assessment of } \\
\text { criteria } o_{i k l}[\mathrm{pt}]\end{array}$} & \multicolumn{2}{|c|}{3.32} & \multicolumn{2}{|c|}{1.54} & \multicolumn{2}{|c|}{3.96} & \multicolumn{2}{|c|}{1.88} & \multicolumn{2}{|c|}{4.81} & & .88 & 2.6 & 69 \\
\hline
\end{tabular}


Table 2. Assessment of $r$ variant influence on improving the $P_{\text {karl }}$ criteria values for $a=1, l=1$

\begin{tabular}{|c|c|c|c|c|c|c|c|c|c|}
\hline \multirow{3}{*}{$\begin{array}{c}\text { Building } \\
\text { element } \\
a\end{array}$} & \multirow{3}{*}{\multicolumn{2}{|c|}{$\begin{array}{c}\text { Repair variant } \\
r\end{array}$}} & \multicolumn{7}{|c|}{$P_{\text {karl }}$} \\
\hline & & & \multicolumn{7}{|c|}{$k$ criterion number } \\
\hline & & & 1 & 2 & 3 & 4 & 5 & 6 & 7 \\
\hline \multirow{3}{*}{$\begin{array}{l}\text { External } \\
\text { wall } \\
\text { (facade) }\end{array}$} & 1 & $\begin{array}{l}\text { repair, thermal insulation - } \\
\text { polystyrene, plaster }\end{array}$ & $\mathrm{L}$ & $\mathrm{VL}$ & M & M & $-\mathrm{L}$ & $\mathrm{N}$ & $\mathrm{L}$ \\
\hline & 2 & $\begin{array}{l}\text { repair, thermal insulation - } \\
\text { wool, plaster }\end{array}$ & $\mathrm{L}$ & $\mathrm{VL}$ & $\mathrm{L} / \mathrm{VL}$ & $\mathrm{VL} / \mathrm{L}$ & VL & $\mathrm{N}$ & $\mathrm{L}$ \\
\hline & 3 & repair, thermal insulation, dry panels & $\mathrm{L}$ & $\mathrm{VL}$ & $\mathrm{L} / \mathrm{VL}$ & $\mathrm{VL} / \mathrm{L}$ & VL & $\mathrm{N}$ & $\mathrm{VL}$ \\
\hline
\end{tabular}

For each $r$-th repair variant of an $a$-th element, the increase or decrease in value for the assumed building condition criteria was estimated. Their value is calculated on the basis of the Eq. (2). Defining the total increase for each $r$-th repair variant $\left(\Delta S=\sum_{k=1}^{m} p_{k r l} \cdot v_{k}\right)$ required determination of the significance of the assumed building condition criteria $\left(v_{k}\right)$. A group of 15 experts were asked to conduct research. It consisted of scientists, building managers and experts of building assessment. Calculations were done with the fuzzy expansion of the AHP method (Jaśkowski et al. 2010). The following weight values were obtained: $v_{1}=0.25$, $v_{2}=0.19, v_{3}=0.10, v_{4}=0.07, v_{5}=0.13, v_{6}=0.11$ and $v_{7}=0.15$. See Table 3 for the calculation results.

Table 3. Increase in the value of criteria for suggested repairs in the first building $(l=1)$

\begin{tabular}{|c|c|c|c|c|c|c|c|c|c|c|c|c|}
\hline \multirow{3}{*}{\multicolumn{2}{|c|}{$\begin{array}{l}\text { Building ele- } \\
\text { ment } \\
a\end{array}$}} & & \multirow{3}{*}{$\begin{array}{c}\text { Repair variant } \\
r\end{array}$} & \multicolumn{7}{|c|}{$p_{k r l}[\mathrm{pt}]$} & \multirow{3}{*}{$\begin{array}{l}\Delta S \\
{[\mathrm{pt}]}\end{array}$} & \multirow{3}{*}{$\begin{array}{l}K_{r l} \\
{[€]}\end{array}$} \\
\hline & & & & \multicolumn{7}{|c|}{$k$ building condition criterion number } & & \\
\hline & & & & 1 & 2 & 3 & 4 & 5 & 6 & 7 & & \\
\hline \multirow{3}{*}{1} & \multirow{3}{*}{$\begin{array}{l}\text { External } \\
\text { walls } \\
\text { (facade) }\end{array}$} & 1 & $\begin{array}{l}\text { repair, thermal } \\
\text { insulation - ex- } \\
\text { panded polysty- } \\
\text { rene, plaster }\end{array}$ & 1.32 & 2.7 & 1.23 & 0.77 & -0.59 & - & 1.2 & 0.391 & 95000 \\
\hline & & 2 & $\begin{array}{l}\text { repair, thermal } \\
\text { insulation - wool, } \\
\text { plaster }\end{array}$ & 1.32 & 2.7 & 1.97 & 1.38 & 0.84 & - & 1.2 & 0.496 & 102500 \\
\hline & & 3 & $\begin{array}{l}\text { repair, thermal } \\
\text { insulation, dry } \\
\text { panels }\end{array}$ & 1.32 & 2.7 & 1.97 & 1.38 & 0.84 & - & 1.71 & 0.523 & 120000 \\
\hline \multirow{4}{*}{2} & \multirow{4}{*}{ Roof } & 1 & $\begin{array}{l}\text { repair, coat repla- } \\
\text { cement, thermal } \\
\text { insulation, wool }\end{array}$ & 0.71 & 1.12 & 1.04 & 1.22 & 0.9 & 0.7 & 0.39 & 0.29 & 30825 \\
\hline & & 2 & $\begin{array}{l}\text { see above, thermal } \\
\text { insulation, } \\
\text { expanded } \\
\text { polystyrene }\end{array}$ & 0.71 & 1.12 & 0.58 & 0.95 & -0.63 & 0.7 & 0.39 & 0.198 & 28625 \\
\hline & & 3 & $\begin{array}{l}\text { repair, coat } \\
\text { replacement }\end{array}$ & 0.71 & - & - & 0.68 & 0 & 0.49 & 0.39 & 0.118 & 21400 \\
\hline & & 4 & $\begin{array}{l}\text { repair, spray-on } \\
\text { foam }\end{array}$ & 0.71 & 0.34 & 0.35 & 0.68 & -0.63 & 0.49 & 0.28 & 0.118 & 19025 \\
\hline
\end{tabular}


End of Table 3

\begin{tabular}{|c|c|c|c|c|c|c|c|c|c|c|c|c|}
\hline \multirow{3}{*}{\multicolumn{2}{|c|}{$\begin{array}{l}\text { Building ele- } \\
\text { ment } \\
a\end{array}$}} & \multirow{3}{*}{\multicolumn{2}{|c|}{$\begin{array}{c}\text { Repair variant } \\
r\end{array}$}} & \multicolumn{7}{|c|}{$p_{k r l}[\mathrm{pt}]$} & \multirow{3}{*}{$\begin{array}{l}\Delta S \\
{[\mathrm{pt}]}\end{array}$} & \multirow{3}{*}{$\begin{array}{l}K_{r l} \\
{[€]}\end{array}$} \\
\hline & & & & \multicolumn{7}{|c|}{$k$ building condition criterion number } & & \\
\hline & & & & 1 & 2 & 3 & 4 & 5 & 6 & 7 & & \\
\hline \multirow{3}{*}{3} & \multirow{3}{*}{ Vestibule } & 1 & repair, painting & 0.12 & - & - & 0.29 & - & 0.13 & 0.35 & 0.041 & 6734 \\
\hline & & 2 & $\begin{array}{l}\text { see above, flooring } \\
\text { replacement }\end{array}$ & 0.17 & - & - & 0.29 & - & 0.63 & 0.49 & 0.071 & 10934 \\
\hline & & 3 & $\begin{array}{l}\text { rebuilding, ramp, } \\
\text { handrails }\end{array}$ & 0.17 & - & - & 0.29 & - & 1.13 & 0.7 & 0.102 & 17946.5 \\
\hline \multirow{3}{*}{4} & \multirow{3}{*}{ Balconies } & 1 & $\begin{array}{l}\text { repair of balcony } \\
\text { slab and plaster }\end{array}$ & 1.26 & - & - & 0.36 & - & 0.69 & 0.39 & 0.165 & 8582.8 \\
\hline & & 2 & $\begin{array}{l}\text { repair, thermal } \\
\text { insulation, clad- } \\
\text { ding }\end{array}$ & 1.26 & 0.19 & - & 0.5 & - & 0.59 & 0.46 & 0.181 & 44429 \\
\hline & & 3 & $\begin{array}{l}\text { see above, railing } \\
\text { replacement }\end{array}$ & 1.26 & 0.19 & - & 0.5 & - & 0.69 & 0.54 & 0.189 & 51850.8 \\
\hline \multirow{3}{*}{5} & \multirow{3}{*}{$\begin{array}{l}\text { External } \\
\text { joinery }\end{array}$} & 1 & $\begin{array}{l}\text { replacement, seal- } \\
\text { ing, painting }\end{array}$ & - & 0.17 & 0.19 & 0.12 & - & 0.17 & 0.7 & 0.064 & 6250 \\
\hline & & 2 & $\begin{array}{l}\text { replacement } \\
\text { (wooden joinery) }\end{array}$ & - & 1.71 & 1.89 & 1.17 & - & 0.56 & 0.91 & 0.276 & 42500 \\
\hline & & 3 & $\begin{array}{l}\text { replacement (PVC } \\
\text { joinery) }\end{array}$ & - & 1.71 & 1.89 & 1.17 & -0.67 & 0.56 & 0.91 & 0.246 & 36250 \\
\hline \multirow[b]{2}{*}{6} & \multirow{2}{*}{$\begin{array}{l}\text { Partition } \\
\text { walls }\end{array}$} & 1 & $\begin{array}{l}\text { repair of walls, } \\
\text { plaster }\end{array}$ & - & - & - & - & - & 0.2 & 0.12 & 0.014 & 13130.3 \\
\hline & & 2 & $\begin{array}{l}\text { repair of walls, } \\
\text { plaster replace- } \\
\text { ment }\end{array}$ & - & - & - & - & - & 0.28 & 0.24 & 0.023 & 17754.8 \\
\hline \multirow{2}{*}{7} & \multirow{2}{*}{$\begin{array}{l}\text { Electrical } \\
\text { system }\end{array}$} & 1 & $\begin{array}{l}\text { replacement of } \\
\text { installations and } \\
\text { fittings }\end{array}$ & - & 0.03 & - & - & 0.64 & 0.63 & 0.21 & 0.066 & 38875.5 \\
\hline & & 2 & $\begin{array}{l}\text { repair of installa- } \\
\text { tions and replace- } \\
\text { ment of fittings }\end{array}$ & - & 0.1 & - & - & 0.32 & 0.32 & 0.06 & 0.036 & 8743.8 \\
\hline \multirow[b]{2}{*}{8} & \multirow{2}{*}{$\begin{array}{l}\text { Central } \\
\text { heating } \\
\text { installation }\end{array}$} & 1 & $\begin{array}{l}\text { repair of installa- } \\
\text { tions }\end{array}$ & - & 0.24 & - & 0.32 & - & 0.25 & 0.06 & 0.036 & 11325 \\
\hline & & 2 & $\begin{array}{l}\text { comprehensive } \\
\text { replacement of } \\
\text { installations }\end{array}$ & - & 0.81 & - & 0.63 & - & 0.49 & 0.21 & 0.099 & 45112.5 \\
\hline 9 & $\begin{array}{l}\text { Basement } \\
\text { floors }\end{array}$ & 1 & $\begin{array}{l}\text { thermal insulation } \\
\text { (mineral wool) }\end{array}$ & - & 0.81 & - & 0.24 & 0.55 & - & 0.36 & 0.451 & 20670 \\
\hline \multirow{2}{*}{10} & \multirow{2}{*}{$\begin{array}{l}\text { Internal } \\
\text { stairs }\end{array}$} & 1 & $\begin{array}{l}\text { repair of cladding, } \\
\text { plaster and rail- } \\
\text { ings }\end{array}$ & - & 0 & - & 0.13 & - & 0.09 & 0.45 & 0.03 & 7695.8 \\
\hline & & 2 & $\begin{array}{l}\text { replacement of } \\
\text { cladding, plaster, } \\
\text { railings }\end{array}$ & - & 0 & - & 0.25 & - & 0.18 & 1.12 & 0.071 & 21710.5 \\
\hline \multirow[t]{2}{*}{11} & \multirow{2}{*}{$\begin{array}{l}\text { Basement } \\
\text { walls }\end{array}$} & 1 & $\begin{array}{l}\text { replacement of } \\
\text { anti-moisture in- } \\
\text { sulation }\end{array}$ & 0.55 & 0 & - & 0.88 & - & - & 0.29 & 0.084 & 19107.5 \\
\hline & & 2 & $\begin{array}{l}\text { see above, thermal } \\
\text { insulation }\end{array}$ & 0.78 & 0.18 & - & 1.26 & - & - & 0.42 & 0.132 & 23627.5 \\
\hline
\end{tabular}


The developed model was used to solve two problems. Firstly, calculations were conducted with the view to determining the increase in the building condition value for six accounting periods $(3,6,9,12,15$ and 20 years) assuming various budget amounts at disposal which is calculated on the basis of the assumed sum of the renovation reserve contributions $s$. The model function consists in defining the scope of renovation most advantageous from the point of view of the improvement of the three buildings conditions. See Table 4 for the calculation results.

Table 4. Condition assessment of three buildings $S_{i}$ for $s=0.225, \ldots, 0.475 € / \mathrm{m}^{2}$ and $i=3, \ldots, 20$ years

\begin{tabular}{|c|c|c|c|c|c|c|}
\hline \multirow{2}{*}{$\begin{array}{c}\text { Renovation con- } \\
\text { tribution } \\
s\left[€ / \mathrm{m}^{2}\right]\end{array}$} & \multicolumn{7}{|c|}{ Mailding condition $S_{i}[\mathrm{pt}]$} \\
\cline { 2 - 7 } & 3 & 6 & 9 & 12 & 15 & 20 \\
\hline 0.225 & 4.29 & 4.78 & 5.12 & 5.69 & 6.23 & 6.68 \\
\hline 0.275 & 4.41 & 4.99 & 5.66 & 5.76 & 6.39 & 7.17 \\
\hline 0.325 & 4.45 & 5.10 & 5.88 & 6.46 & 6.95 & 7.69 \\
\hline $\mathbf{0 . 3 7 5}$ & $\mathbf{4 . 5 3}$ & $\mathbf{5 . 3 3}$ & $\mathbf{5 . 7 9}$ & $\mathbf{6 . 6 4}$ & 7.26 & 7.90 \\
\hline 0.425 & 4.52 & 5.45 & 6.36 & 7.04 & 7.62 & 8.05 \\
\hline 0.475 & 4.63 & 5.72 & 6.58 & 7.12 & 7.83 & 8.09 \\
\hline
\end{tabular}

The above-mentioned results make it possible to select the most appropriate (acceptable) renovation financing variant. It is expressed by the manager's acceptance (in agreement with residents) of the amount of the renovation reserve contribution, which allows for improving the building condition up the value agreed upon. Table 5 shows repairs in the three analysed buildings possible to be performed only if the amount of the contribution is $s=0.375$ $€ / \mathrm{m}^{2}$ during the maintenance period of 20 years. The order and dates of their performance depends on the possibilities of their financing in individual years of the analysed $i$-th maintenance period. Calculations of the building condition value, costs of the $K_{r l}$ repair variant implementation and $B$ budget amounts in individual years are also provided.

The second problem to be solved by the developed model was to find the most favourable scope of renovation which would ensure the assumed $S_{i}$ building condition during the $n$-th maintenance period. In the example, the authors look for a scope of renovation during each of the assumed $i$-th maintenance periods, i.e. from 3 to 15 years, which, at the lowest completion costs, will make it possible to obtain the minimum assumed building condition values $g_{k}=3,4, \ldots, 7$ points. See table 6 for results.

Table 7 shows the sequence of repairs in the analysed buildings in order to obtain the building condition value of $S_{i}=7.45$ points during a maintenance period of 15 years. It also includes calculations of the costs of repair variants $K_{r}$ and amounts in the budget $B$ for the renovation reserve contribution of $s=0.5 € / \mathrm{m}^{2}$, which results from the total costs of all repairs during the whole $n$-th maintenance period.

Using the second model variant, more detailed calculations were conducted to find the most favourable scope of renovation in buildings to obtain the assumed assessment values for each criterion. The calculations assume the maintenance period of 9 years. It was assumed 
that the building condition criteria values sought for must not be lower than, respectively, 4, 5, 6 and 7 points.

While analysing the calculation results (Table 8) for obtaining the assumed condition of buildings $S_{i}$ and the cost $K$ of ensuring it, it may be noticed that better efficiency indicator $E=\frac{S_{i}}{K[\mathrm{mln}]}$ (profitability) of funds is renovations of assumed lower value $h$ (the best $E=$ 13.22 for $S=5.29$ point).

Table 5. Schedule of repair works performance for $i=1,2, \ldots, n=20$ years and $s=0.375 € / \mathrm{m}^{2}$

\begin{tabular}{|c|c|c|c|c|c|c|c|c|c|c|c|c|c|c|c|c|c|}
\hline \multirow{3}{*}{$\begin{array}{c}\text { Building } \\
\text { number } \\
l\end{array}$} & \multicolumn{17}{|c|}{ Maintenance period $i$ [years] } \\
\hline & 1 & 2 & 3 & 4 & 5 & 6 & 7 & 8 & 10 & 11 & 12 & 14 & 15 & 17 & 18 & 19 & 20 \\
\hline & \multicolumn{17}{|c|}{ Repair/ variant number } \\
\hline 1 & $2 / 1$ & $4 / 1$ & - & $3 / 2$ & $5 / 2$ & $11 / 2$ & & $19 / 1$ & - & - & - & $1 / 2$ & $7 / 2$ & - & $10 / 2$ & $8 / 2$ & $6 / 2$ \\
\hline 2 & $2 / 1$ & $4 / 1$ & - & - & - & $9 / 1$ & $3 / 2$ & & & $5 / 2$ & $11 / 2$ & & $10 / 2$ & $1 / 2$ & $8 / 1$ & - & $7 / 2$ \\
\hline 3 & $2 / 1$ & $12 / 2$ & $5 / 2$ & $\begin{array}{c}3 / 3 \\
10 / 1\end{array}$ & - & - & $\begin{array}{c}8 / 2 \\
11 / 2\end{array}$ & $4 / 1$ & $1 / 2$ & - & - & - & $9 / 1$ & - & $7 / 2$ & - & $6 / 2$ \\
\hline $\begin{array}{l}\text { Repair } \\
\text { variant } \\
\text { costs } \\
K_{r}[€]\end{array}$ & $\begin{array}{l}\text { ㅇ } \\
\text { ○ } \\
\infty\end{array}$ & $\begin{array}{l}10 \\
10 \\
0 \\
\infty \\
0 \\
n\end{array}$ & $\begin{array}{l}8 \\
8 \\
\text { f }\end{array}$ & \begin{tabular}{l}
$\stackrel{+}{\infty}$ \\
$\stackrel{1}{\sim}$ \\
\multirow{f}{*}{}
\end{tabular} & $\begin{array}{l}8 \\
\stackrel{1}{1} \\
\text { ㄱ }\end{array}$ & $\begin{array}{l}\text { ñ } \\
\text { ָ̊ } \\
\text { F }\end{array}$ & $\begin{array}{l}\text { mे } \\
\text { } \\
\text { లి }\end{array}$ & $\begin{array}{l}\infty \\
\text { î } \\
\text { ì } \\
\text { ปे }\end{array}$ & $\begin{array}{l}8 \\
\text { in } \\
\text { ล }\end{array}$ & $\begin{array}{l}n \\
\hat{N} \\
\text { in } \\
\text { f }\end{array}$ & $\begin{array}{l}8 \\
\text { in } \\
\stackrel{\lambda}{1}\end{array}$ & $\begin{array}{l}8 \\
0 \\
i n \\
0 \\
0\end{array}$ & 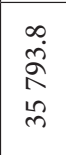 & $\begin{array}{l}\stackrel{0}{\grave{n}} \\
\sigma \\
\sigma\end{array}$ & $\begin{array}{l}n ? \\
8 \\
8 \\
0 \\
0\end{array}$ & $\begin{array}{l}\stackrel{n}{3} \\
\stackrel{7}{q}\end{array}$ & 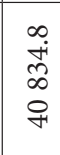 \\
\hline $\begin{array}{l}\text { Budget } \\
B[€]\end{array}$ & $\begin{array}{l}8 \\
i \\
\infty \\
\infty\end{array}$ & 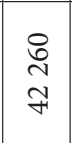 & \begin{tabular}{l}
$\qquad n$ \\
\multirow{2}{R}{} \\
\multirow{2}{f}{}
\end{tabular} & 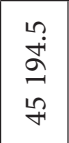 & 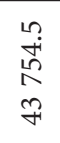 & 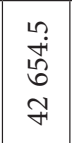 & $\begin{array}{l}\text { Ŵ} \\
\text { r } \\
\text { f }\end{array}$ & $\begin{array}{l}\infty \\
\underset{F}{F} \\
\text { F }\end{array}$ & $\begin{array}{l}m \\
13 \\
2 \\
8 \\
0\end{array}$ & $\begin{array}{l}m \\
10 \\
\infty \\
\infty \\
\forall\end{array}$ & 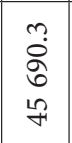 & 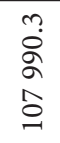 & 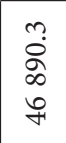 & $\begin{array}{l}n \\
20 \\
\infty \\
\infty \\
n\end{array}$ & \begin{tabular}{l}
$n ?$ \\
60 \\
0 \\
0 \\
\multirow{4}{4}{}
\end{tabular} & $\begin{array}{l}0 \\
\infty \\
m \\
\stackrel{n}{q}\end{array}$ & $\begin{array}{l}n \\
\text { ñ } \\
7\end{array}$ \\
\hline$S_{i}[\mathrm{pt}]$ & $\begin{array}{l}\infty \\
\dot{n} \\
\dot{m}\end{array}$ & $\stackrel{\overbrace{}}{+}$ & $\stackrel{n}{+}$ & $\begin{array}{l}\mathscr{\infty} \\
+ \\
+\end{array}$ & $\stackrel{ }{\circ}$ & $\stackrel{m}{m}$ & $\begin{array}{l}\sqrt{n} \\
\text { in }\end{array}$ & $\begin{array}{l}\stackrel{2}{\hat{~}} \\
\text { in }\end{array}$ & $\stackrel{m}{\sigma}$ & th. & تु & $\stackrel{m}{\frac{M}{n}}$ & 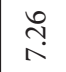 & $\stackrel{H}{\circ}$ & $\stackrel{+}{\stackrel{N}{N}}$ & $\stackrel{\leftrightarrow}{\stackrel{\infty}{N}}$ & $\stackrel{\circ}{\curvearrowright}$ \\
\hline
\end{tabular}

Table 6. Assessment of building condition criteria $o_{i k l}$ of three buildings $L=3$, for $i=3, \ldots, 15$ years

\begin{tabular}{|c|c|c|c|c|c|c|c|c|}
\hline \multirow{2}{*}{$\begin{array}{c}\text { Maintenance } \\
\text { period } \\
i \text { [years] }\end{array}$} & \multicolumn{6}{|c|}{ Assessment of $k$-th building condition criteria $\sum_{l=1}^{L} o_{i k l}$ [pt] } & \multirow{2}{*}{$\begin{array}{c}\text { Building con- } \\
\text { dition } \\
S_{i}[\mathrm{pt}]\end{array}$} \\
\cline { 2 - 9 } & 1 & 2 & 3 & 4 & 5 & 6 & 7 & 3.83 \\
\hline 3 & 3.98 & 3.25 & 4.18 & 3.17 & 5.03 & 3.47 & 3.63 & 4.54 \\
\hline 6 & 4.58 & 4.32 & 4.83 & 4.16 & 5.01 & 4.18 & 4.59 & 5.40 \\
\hline 9 & 5.39 & 5.19 & 6.05 & 5.17 & 5.35 & 5.29 & 5.46 & 6.51 \\
\hline 12 & 6.47 & 6.37 & 7.09 & 6.63 & 6.14 & 6.61 & 6.54 & 7.45 \\
\hline $\mathbf{1 5}$ & $\mathbf{7 . 2 0}$ & $\mathbf{7 . 8 8}$ & $\mathbf{8 . 2 5}$ & $\mathbf{7 . 6 8}$ & $\mathbf{7 . 0 8}$ & $\mathbf{7 . 0 1}$ & $\mathbf{7 . 3 4}$ & \\
\hline
\end{tabular}


Table 7. Schedule of repair works performance in three buildings for $S_{i}=7.45$ points, $i=1,2, \ldots, n$

\begin{tabular}{|c|c|c|c|c|c|c|c|c|c|c|c|c|c|c|c|}
\hline \multirow{3}{*}{$\begin{array}{c}\text { Building } \\
\text { number } \\
l\end{array}$} & \multicolumn{14}{|c|}{ Maintenance (accounting) period $i$ [years] } & \multirow{3}{*}{$\begin{array}{c}\text { Renovation } \\
\text { cost } \\
{[€]}\end{array}$} \\
\hline & 1 & 2 & 3 & 4 & 5 & 6 & 7 & 8 & 9 & 10 & 11 & 12 & 14 & 15 & \\
\hline & \multicolumn{14}{|c|}{ Repair/variant number } & \\
\hline 1 & $3 / 3$ & $1 / 2$ & $7 / 2$ & - & - & \begin{tabular}{|l|}
$5 / 3$ \\
$6 / 2$
\end{tabular} & $4 / 1$ & - & - & - & - & $2 / 1$ & - & $8 / 1$ & 233927.75 \\
\hline 2 & $4 / 1$ & & $7 / 1$ & - & - & $11 / 2$ & - & $3 / 3$ & - & $5 / 1$ & $1 / 2$ & - & - & $\begin{array}{l}2 / 1 \\
8 / 1 \\
9 / 1\end{array}$ & 232604.25 \\
\hline 3 & $11 / 1$ & $9 / 1$ & & $10 / 1$ & $4 / 4$ & & $2 / 1$ & & $5 / 2$ & $\begin{array}{l}7 / 1 \\
8 / 1\end{array}$ & $12 / 2$ & $3 / 3$ & $1 / 2$ & $6 / 2$ & 439990 \\
\hline $\begin{array}{l}\text { Repair } \\
\text { costs } \\
{[€]}\end{array}$ & \begin{tabular}{l}
$m$ \\
\multirow{H}{*}{} \\
0 \\
$m$ \\
$m$
\end{tabular} & $\begin{array}{l}8 \\
8 \\
m \\
=\end{array}$ & $\begin{array}{l}\infty \\
\stackrel{\infty}{2} \\
\text { r̊ }\end{array}$ & $\begin{array}{l}\stackrel{2}{\Lambda} \\
\underset{\sigma}{-1}\end{array}$ & 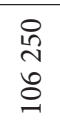 & \begin{tabular}{l}
$\infty$ \\
$\stackrel{\infty}{+}$ \\
$\stackrel{1}{1}$ \\
\multirow{1}{n}{}
\end{tabular} & $\begin{array}{l}\stackrel{\infty}{\infty} \\
\stackrel{\sim}{\sim} \\
\infty \\
\infty \\
\infty\end{array}$ & 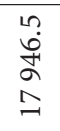 & $\begin{array}{l}8 \\
8 \\
\dddot{f}\end{array}$ & $\begin{array}{l}\stackrel{n}{n} \\
\text { m } \\
\stackrel{\infty}{\infty}\end{array}$ & $\begin{array}{l}\stackrel{0}{2} \\
\text { م⿱ } \\
\text { ․ }\end{array}$ & $\begin{array}{l}8 \\
i n \\
0 \\
\qquad\end{array}$ & $\begin{array}{l}8 \\
\text { in } \\
\text { a }\end{array}$ & $\begin{array}{l}\stackrel{\sim}{N} \\
\underset{\infty}{\infty} \\
\infty\end{array}$ & \\
\hline $\begin{array}{l}\text { Budget } \\
{[€]}\end{array}$ & 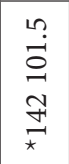 & 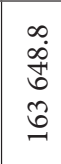 & $\begin{array}{l}n \\
0 \\
\stackrel{0}{1} \\
\stackrel{0}{0}\end{array}$ & $\begin{array}{l}\infty \\
\hat{n} \\
\hat{L} \\
0 \\
0 \\
=\end{array}$ & 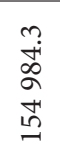 & $\begin{array}{l}\infty \\
\stackrel{\infty}{m} \\
m \\
m \\
0 \\
0\end{array}$ & $\begin{array}{l}\tilde{n} \\
\stackrel{\infty}{+} \\
\infty \\
\infty\end{array}$ & 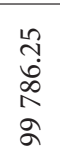 & 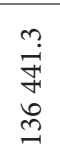 & 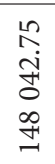 & $\begin{array}{l}\stackrel{n}{0} \\
\text { N } \\
\triangleq\end{array}$ & $\begin{array}{l}n \\
\text { กิ } \\
\alpha \\
\text { o }\end{array}$ & $\begin{array}{l}\tilde{n} \\
\text { तु } \\
\tilde{I}\end{array}$ & $\begin{array}{l}\stackrel{2}{N} \\
\stackrel{\infty}{\infty}\end{array}$ & 906522 \\
\hline
\end{tabular}

Note: ${ }^{\star} C+c$, where: $c=0.5 € / \mathrm{m}^{2} \cdot 9200 \mathrm{~m}^{2} \cdot 12 \approx 54601.5 €, C=87500 €$.

Table 8. Cost of building renovation $K$ for assumed criteria assessment values $h=4,5,6,7 \mathrm{pt}, i=9$ years.

\begin{tabular}{|c|c|c|c|c|c|c|c|c|c|c|}
\hline \multirow{2}{*}{$\begin{array}{c}\text { Assumed } \\
\text { value } h \\
{[\mathrm{pt}]}\end{array}$} & \multicolumn{6}{|c|}{ Assessment of $k$-th building condition criteria $\sum_{l=1}^{L} o_{i k l}[\mathrm{pt}]$} & \multirow{2}{*}{$\mathrm{K}[€]$} & \multirow{2}{*}{$S_{i}[\mathrm{pt}]$} & $E$ \\
\cline { 2 - 10 } & 1 & 2 & 3 & 4 & 5 & 6 & 7 & & & \\
\hline 4 & 4.49 & 4.06 & 4.35 & 4.39 & 4.40 & 4.46 & 4.20 & 356697.0 & 4.33 & 12.14 \\
\hline 5 & 5.39 & 5.02 & 5.36 & 5.42 & 5.44 & 5.29 & 5.27 & 400012.5 & 5.29 & 13.22 \\
\hline 6 & 6.56 & 6.01 & 6.01 & 6.61 & 6.41 & 6.01 & 6.37 & 513978.8 & 6.29 & 12.24 \\
\hline 7 & 7.07 & 7.46 & 7.25 & 7.49 & 7.16 & 7.02 & 7.16 & 1003263.8 & 7.21 & 7.18 \\
\hline
\end{tabular}

\section{Conclusions}

The decision-making model presented in this paper constitutes a multi-stage approach to planning maintenance expenditures for multi-family residential buildings. Elaboration of this model required implementing various calculation tools necessary to solve individual problems. The first and foremost problem is the building condition diagnostics which was conducted by means of linguistic terms allowing us to define the elements included in the assessment of individual requirements in a simple and understandable manner. Determination of the most favourable scope of renovation for buildings required employing a comprehensive indicator assessed by means of the AHP multiple-criteria method. Elaboration of the renovation plan for buildings was the target stage of supporting managers in the building maintenance process. The task dealt with creating a linear model to allocate the range of renovation with financial restraints. It enables a manger to elaborate various variants of a 
renovation plan and, with residents' participation, select a variant tailored to their financial capabilities.

The elaborated model addresses the need to plan maintenance of residential real estate. It is an innovative solution for a decision-making problem managers of multi-family buildings struggle with. The multistage approach of model allows its partial or entire utilization. It takes into account financial specificity and limits usually impacting decisions. Improving the functional quality of residential buildings is a tangible result of implementing the suggested approach.

\section{Acknowledgements}

The studies have been financed from statutory funds allocated by the Ministry of Science and Higher Education (S/63/2015).

\section{References}

Alchimoviene, J.; Raslanas, S. 2011. Sustinable renovation and evaluation of block of multi-apartment house, in The $8^{\text {th }}$ International Conference "Environmental Engineering", 19-20 May 2011, Vilnius, Lithuania.

Bahr, C.; Lennerts, K. 2010. Quantitative validation of budgeting methods and suggestion of a new calculation method for the determination of maintenance costs, Journal of Facilities Management 8(1): 47-63. https://doi.org/10.1108/14725961011019076

Borissova, D.; Mustakerov, I. 2012. An integrated framework of designing a decision support system for engineering predictive maintenance, International Journal "Information Technologies and Knowledge" 6(4): 366-376.

Bucoń, R.; Sobotka, A. 2015. Decision making model for choosing residential building repair variants, Journal of Civil Engineering and Management 21(7): 893-901. https://doi.org/10.3846/13923730.2014.895411

Bucoń, R.; Tomczak, M. 2016. Supporting building administrator's decisions in determining maintenance costs of residential buildings, Engineering Structures and Technologies 8(1): 15-22. https://doi.org/10.3846/2029882X.2016.1170641

Caccavelli, D.; Gugerli, H. 2002. TOBUS - a European diagnosis and decision-making tool for office building upgrading, Energy and Buildings 34(2): 113-119. https://doi.org/10.1016/S0378-7788(01)00100-1

Christen, M.; Schroeder, J.; Wallbaum, H. 2014. Evaluation of strategic building maintenance and refurbishment budgeting method Schroeder, International Journal of Strategic Property Management 18(4): 393-406. https://doi.org/10.3846/1648715X.2014.971917

Chua, S. J. L.; Ali, A. S.; Alias, A. B. 2015. Implementation of Analytic Hierarchy Process (AHP) decision making framework for building maintenance procurement selection: case study of Malaysian public universities, Maintenance and Reliability 17(5): 7-18.

Dascalaki, E.; Balaras, C. A. 2004. XENIOS - a methodology for assessing refurbishment scenarios and the potential of applications of RES and RUE in hotels, Energy and Buildings 36(11): 1091-1105. https://doi.org/10.1016/j.enbuild.2004.03.007

Dukić, D.; Trivunić, M.; Starčev-Ćurčin, A. 2013. Computer-aided building maintenance with "BASEFM" program, Automation in Construction 30: 57-69. https://doi.org/10.1016/j.autcon.2012.10.001 
Ho, D. C. W.; Chau, K. W.; Cheung, A. K. C.; Yau, Y.; Wong, S. K.; Leung, H. F.; Lau, S. S. Y.; Wong, W. S. 2008. A survey of the health and safety conditions of apartment buildings in Hong Kong, Building and Environment 43(5): 764-775. https://doi.org/10.1016/j.buildenv.2007.01.035

Ho, D. C. W.; Yau, Y.; Poon, S. W.; Liusman, E. 2012. Achieving sustainable urban renewal in Hong Kong: a strategy for dilapidation assessment of high rises, Journal of Urban Planning and Development 138(2): 153-165. https://doi.org/10.1061/(ASCE)UP.1943-5444.0000104

Jaśkowski, P.; Biruk, S.; Bucoń, R. 2010. Assessing contractor selection criteria weights with fuzzy AHP method application in group decision environment, Automation in Construction 19(2): 120-126. https://doi.org/10.1016/j.autcon.2009.12.014

Journal of Laws. 1997. No. 115, Item. 741. The Real estate management act from 21 August 1997, Polish Standard.

Juan, Y. K.; Kim, J. H.; Roper, K.; Lacouture, D. C. 2009. GA - based decision support system for housing condition assessment and refurbishment strategies, Automation in Construction 18(4): 394-401. https://doi.org/10.1016/j.autcon.2008.10.006

Kaklauskas, A.; Tupenaite, L.; Kanapeckiene, L. 2008. Automated selection of value efficient buildings refurbishment alternatives, in The $25^{\text {th }}$ International Symposium on Automation and Robotics in Construction ISARC-2008, 26-29 June 2008, Vilnius, Lithuania. https://doi.org/10.3846/isarc.20080626.312

Kaklauskas, A.; Zavadskas, E. K.; Raslanas, S. 2005. Multivariant design and multiple criteria analysis of building refurbishments, Energy and Buildings 37(4): 361-372.

https://doi.org/10.1016/j.enbuild.2004.07.005

Kasprowicz, T. 2005. Modelling of complex small buildings operation and maintenance, in The $9^{\text {th }}$ International Conference on "Inspection, Appraisal - Repairs and Maintenance of Structures", 19-21 October 2005, Fuzhou, China.

Ko, C. H. 2009. RFID-based building maintenance system, Automation in Construction 18(3): 275-284. https://doi.org/10.1016/j.autcon.2008.09.001

Kolokotsa, D.; Diakaki, C.; Grigoroudis, E.; Stavrakakis, G.; Kalaitzakis, K. 2009. Decision support methodologies on the energy efficiency and energy management in buildings, Advances in Building Energy Research 9(3): 121-146. https://doi.org/10.3763/aber.2009.0305

Langevine, R.; Allouche, M.; Abourizk, S. 2006. Decision support tool for the maintenance management of buildings, in Joint International Conference on Computing and Decision Making in Civil and Building Engineering, 14-16 June 2006, Montréal, Canada.

Lounis, Z.; Vanier, D. J. A. 2000. Multiobjective and stochastic system for building maintenance management, Journal of Computer-Aided Civil and Infrastructure Engineering 15(5): 320-329. https://doi.org/10.1111/0885-9507.00196

Medineckiene, M.; Zavadskas, E. K.; Björk, F.; Turskis, Z. 2015. Multi-criteria decision-making system for sustainable building assessment/certification, Archives of Civil and Mechanical Engineering 15(1): 11-18. https://doi.org/10.1016/j.acme.2014.09.001

Mickaityte, A.; Zavadskas, E. K.; Kaklauskas, A.; Tupenaite, L. 2008. The concept model of sustainable buildings refurbishment, International Journal of Strategic Property Management 12(1): 53-68. https://doi.org/10.3846/1648-715X.2008.12.53-68

Mohd-Noor, N.; Hamid, M. Y.; Abdul-Ghani, A. A.; Haron, S. N. 2011. Building maintenance budget determination: an exploration study in the Malaysia government practice, Procedia Engineering 20: 435-444. https://doi.org/10.1016/j.proeng.2011.11.186

Perng, Y. H.; Juan, Y. K.; Hsu, H. S. 2007. Genetic algorithm-based decision support for the restoration budget allocation of historical buildings, Building and Environment 42(2): 770-778.

https://doi.org/10.1016/j.buildenv.2005.09.009 
Rasiulis, R.; Ustinovichius, L.; Vilutiene, T.; Popov, V. 2016. Decision model for selection of modernization measures: public building case, Journal of Civil Engineering and Management 22(1): 124-133. https://doi.org/10.3846/13923730.2015.1117018

Raslanas, S.; Alchimoviene, J.; Banaitienė, N. 2011. Residential areas with apartment houses: analysis of the condition of buildings, planning issues, retrofit strategies and scenarios, International Journal of Strategic Property Management 15(2): 152-172. https://doi.org/10.3846/1648715X.2011.586531

Reed, R.; Wilkinson, S.; Bilos, A.; Schulte, K. W. 2011. A comparison of international sustainable building tools - an update, in The $17^{\text {th }}$ Annual Pacific Rim Real Estate Society Conference, 16-19 January 2011, Gold Coast, Australia.

Straub, A. 2009. Dutch standard for condition assessment of buildings, Structural Survey 27(1): 23-35. https://doi.org/10.1108/02630800910941665

Yau, Y.; Ho, D. C. W.; Chau, K. W. 2008. Determinants of the safety performance of private multi-storey residential buildings in Hong Kong, Social Indicators Research 89(3): 501-521. https://doi.org/10.1007/s11205-008-9246-3

Yin, H.; Stack, P.; Menzel, K. 2011. Decision support model for building renovation strategies, Computing in Civil Engineering (2011): 834-841.

Zavadskas, E. K.; Kaklauskas, A.; Tupenaite, L.; Mickaityte, M. 2008. Decision-making model for sustainable building refurbishment. Energy efficiency aspect, in The $7^{\text {th }}$ International Conference of Environmental Engineering, 22-23 May 2008, Vilnius, Lithuania, 894-901. 